See discussions, stats, and author profiles for this publication at: https://www.researchgate.net/publication/326233698

\title{
An emended description of Neofusicoccum brasiliense and characterization of Neoscytalidium and Pseudofusicoccum species associated with tropical fruit plants in northeastern Brazil
}

Article in Phytotaxa July 2018

DOI: 10.11646/phytotaxa.358.3.3

CITATIONS

0

7 authors, including:

Cristiano Souza Lima

Universidade Federal do Ceará

17 PUBLICATIONS 164 CITATIONS

SEE PROFILE
READS

58

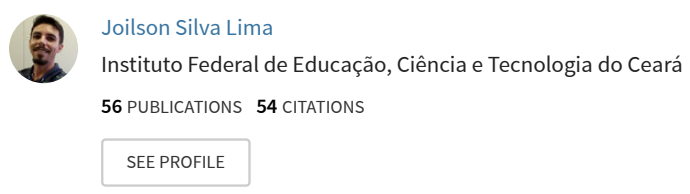

Francisco José Teixeira Gonçalves

Instituto Federal de Mato Grosso do Sul, Brazil, Nova Andradina

10 PUBliCATIONS 23 CITATIONS

SEE PROFILE

Some of the authors of this publication are also working on these related projects:

Project Managing cashew diseases View project

Project Effect of soil and climatic conditions in occurrence of cashew gummosis View project 


\title{
Article
}

https://doi.org/10.11646/phytotaxa.358.3.3

\section{An emended description of Neofusicoccum brasiliense and characterization of Neoscytalidium and Pseudofusicoccum species associated with tropical fruit plants in northeastern Brazil}

\author{
INGRID B.L. COUTINHO*, JOSÉ E. CARDOSO ${ }^{\text {, }}$ CRISTIANO S. LIMA, JOILSON S. LIMA ${ }^{a}$, FRANCISCO J.T. \\ GONÇALVES ${ }^{\mathrm{c}}$, ABIGAIL. M.S. SILVA ${ }^{\mathrm{d}}$ \& FRANCISCO C.O. FREIRE ${ }^{\mathrm{b}}$ \\ ${ }^{a}$ Departamento de Fitotecnia, Universidade Federal do Ceará, 60356-001 Fortaleza, Ceará, Brazil \\ ${ }^{b}$ Embrapa Agroindústria Tropical, 60511-110 Fortaleza, Ceará, Brazil \\ 'Instituto Federal de Mato Grosso do Sul, Nova Andradina, Mato Grosso do Sul, 79750-000 \\ ${ }^{d}$ Departamento de Genética, Universidade Federal de Pernambuco, 50670-901 Recife, Pernambuco, Brazil \\ * Corresponding author: ibernardodelima@gmail.com
}

\begin{abstract}
The Botryosphaeriaceae family is one of the most important groups of plant pathogenic fungi associated with tropical woody species such as Anacardium occidentale (cashew) and Mangifera indica (mango), which are fruiting species with broad distributions and high economic importance in north-eastern Brazil. This study was designed to characterize species of this family associated with cashew, mango and Psidium guajava (guava) that cause dieback and stem and branch cankers. Characterization comprised phylogenetic, morphological, physiological and pathogenic features. The phylogenetic study combined sequences of the internal transcribed spacer (ITS) of the rDNA and partial elongation factor 1- $\alpha$ (EF1- $\alpha$ ) regions of DNA. Measurements of fungal conidia and colony growth on different culture media and at different temperatures were conducted. Pathogenicity tests were also performed through inoculation of different host species. By combining the sequences of the referenced genes, it was possible to identify the following Botryosphaeriaceae species: Neofusicoccum kwambonambiense, Neoscytalidium hyalinum and Pseudofusicoccum stromaticum as the first report in cashew, Neoscytalidium hyalinum in mango and Neofusicoccum brasiliense as the first report in guava. Examination of $N$. brasiliense revealed conidia, providing the first morphological description of the species. Neofusicoccum kwambonambiense did not sporulate, but the other isolates produced conidia with dimensions comparable to those described in the literature. All isolates were virulent to mango fruits and young cashew and "caja-umbu" plants, causing necrotic lesions and gum exudation by the hosts. The isolates of Neofusicoccum were the most aggressive in the inoculated hosts.
\end{abstract}

Keywords: Anacardium occidentale, Botryosphaeriaceae, fungi, Mangifera indica, molecular phylogeny, Psidium guajava

\section{Introduction}

Family Anarcadiaceae includes tropical fruits of high socio-economic importance in Northeast Brazil (Pickel 2008). Of 80 genera and 600 species present in the family, approximately 13 genera and 68 species occur in Brazil (Barroso 1991), among which the cashew tree (Anacardium occidentale) and the mango tree (Mangifera indica) stand out among the species of highest economic and social importance (Marques et al. 2013b). These plant species are either native, such as the cashew, or, in the case of mango introduced a long time ago by the Portuguese. Recently, novel methods of cultivation have rendered plants vulnerable to abiotic stress and thereby favour the occurrence of severe epidemics caused by opportunistic fungi (Freire 1991, Tavares 2002).

Diseases caused by fungi of the family Botryosphaeriaceae stand out, both in this and other pathosystems in Northeast Brazil, because they are polyphagous pathogens that take advantage of physiologically weakened plants growing under stressful conditions. Therefore, this pathogen-host interaction is the target of several studies aimed at the identification and characterization of the pathogenic species involved (Costa et al. 2010, Lima et al. 2013, Marques et al. 2013a,b, Abdollahzadeh et al. 2013, Ismail et al. 2012).

Symptoms such as cankers, gummosis and dieback of Anacardiaceae plants have long been associated with infection by Lasiodiplodia theobromae (Pat.) Griff. \& Maubl. (Freire et al. 2011, Pavilic et al. 2004). However, early 
pathogenic information and recent phylogenetic studies based on molecular techniques provided clear evidence of the association of a complex of cryptic species of Lasiodiplodia and other genera of Botryosphaeriaceae, such as Neofusicoccum Crous Slippers \& A.J.L. Phillips 2006, Neoscytalidium Crous \& Slippers 2006, and Pseudofusicoccum Mohali, Slippers \& Wingf. (Sakalidis et al. 2013, Marques et al. 2013b, Machado et al. 2014, Berraf-Tebbal et al. 2014, Gonçalves et al. 2016).

The Botryosphaeriaceae is a cosmopolitan and polyphagous group of fungi (Denman et al. 2000, Machado et al. 2014). Ecologically this family includes non-host-specific pathogens, saprophytes, endophytes, and latent pathogens, and are generally known as weak pathogens (Denman et al. 2000, Sakalidis et al. 2013, Slippers \& Wingfield 2007).

In the asexual phase, Neofusicoccum, Pseudofusicoccum and Neoscytalidium show Fusicoccum-type conidia, with narrow, ellipsoid to slightly ovoid and thin-walled forms, which makes them morphologically indistinguishable (Crous et al. 2006). The asexual phase is the most common form found in nature; it is easily isolated and exhibits abundant mycelial growth on most culture media but shows poor sporulation (Crous et al. 2006, Phillips et al. 2013). Morphological characteristics are insufficient for identification at the genus level, so molecular analyses are required to achieve a precise diagnosis (Phillips et al. 2013).

The phylogeny of this fungal family undergoes frequent updates due to the description of new species. In addition, reports of new pathogen-host associations and new information regarding their geographic distributions are frequently reported (Phillips et al. 2013, Sakadilis et al. 2013). Phylogenetic studies indicate that the combined analysis of ITS sequences and partial sequences of the EF1 alfa genes are used to delimit species within these genera (Marques et al. 2013a, Phillips et al. 2013, Machado et al. 2014).

The association of these genera with pathosystems has recently increased (Lopes et al. 2014, Gonçalves et al. 2016). Twenty-two species of Neofusicoccum (Berraf-Tebbal et al. 2014), two of Neoscytalidium and six of Pseudofusicoccum have been reported in Brazil (Phillips et al. 2013). In this country, they were isolated in endophytic association with several trees in the "caatinga" ecosystem in Ceará state and have been shown to be potential pathogens when inoculated on mango fruits and "caja-umbu" (Spondias mombin $\times$ S. tuberosa) trees (Gonçalves et al. 2016). In terms of their pathogenic behaviour, they have been associated with dieback and stalk rot in mango fruits (Marques et al. 2013b), while Neoscytalidium hyalinum has been reported in association with black rot of cassava (Manihot esculenta) (Machado et al. 2014b) and Jatropha curcas (Machado et al. 2014a).

In cashew and other commonly grown fruit trees in Northeast Brazil, the occurrence of canker and dieback was associated only with Lasiodiplodia species until recently. Two new species of Botryosphaeriaceae involved were phylogenetically characterized and described in association with these symptoms (Coutinho et al. 2017). In view of such evidence, the present study aimed to characterize the phylogenetic and pathogenic attributes of isolates morphologically identified as belonging to the group of Fusicoccum-like associated with cashew, mango and guava (Psidium guajava) plants in Northeast Brazil.

\section{Materials and methods}

\section{Sampling and fungal isolation}

The samples used in this study were obtained from plants exhibiting cankers or dieback symptoms on stems and branches in different regions throughout northeastern Brazil, from July to November 2013.

Infected tissues or organs were transported to the Laboratory of Phytopathology of Embrapa Agroindústria Tropical, Fortaleza, Ceará state. Fungal isolation, culturing, and incubation were done according to procedures described earlier (Coutinho et al. 2017). Monosporic cultures were obtained from sporulating colonies, transferred to potato dextrose agar (PDA) slants and stored in a refrigerator at $5{ }^{\circ} \mathrm{C}$.

Sporulating cultures in a potato carrot agar (PCA) medium amended with sterilized pine needles (Mohali et al. 2005) were examined using light microscopy, and isolates with Fusicoccum-like conidium morphology were subjected to DNA extraction, amplification by polymerase chain reaction (PCR) and sequencing of amplified regions.

\section{Molecular characterization}

DNA extraction and amplification were conducted at the Molecular Biology Laboratory of Embrapa Agroindústria Tropical. Selected isolates were grown in potato dextrose broth for 7 days in still culture (Coutinho et al. 2017). The mycelial mass produced was dried at room temperature and used for DNA extraction following a previously described protocol (Cavalcanti et al. 2004). Extracted DNA was quantified using a NanoDrop ${ }^{\circledR}$ 2000c spectrophotometer 
(Thermo Fisher Scientific, Wilmington, DE, USA), version 1.0, and portions of $10 \mathrm{ng} \mu \mathrm{L}^{-1}$ were stored in a $-20{ }^{\circ} \mathrm{C}$ freezer.

The polymerase chain reaction (PCR) mixtures contained genomic DNA $\left(10 \mathrm{ng} \mu \mathrm{L}^{-1}\right), 1 \mathrm{x}$ buffer, dNTP $(0.2 \mathrm{mM})$, $\mathrm{MgCl}_{2}(1.5 \mathrm{mM})$, each primer $(1.5 \mathrm{mM})$, Taq Flexi DNA $(2.5 \mathrm{U} / \mu \mathrm{L})$, and sterile deionized water. The ITS primers were ITS1 and ITS4 (White et al. 1990) and EF1-688F and EF1-1251R primers were used to amplify part of the EF1- $\alpha$ (Alves et al. 2008). The thermal cycle of the PCR consisted of $96{ }^{\circ} \mathrm{C}$ for $1 \mathrm{~min}$ followed by 35 cycles of $30 \mathrm{~s}$ at 94 ${ }^{\circ} \mathrm{C}$ (denaturation), $1 \mathrm{~min}$ at $58{ }^{\circ} \mathrm{C}$ (EF1- $\alpha$ and ITS regions), $1.5 \mathrm{~min}$ at $72{ }^{\circ} \mathrm{C}$ (annealing) and $10 \mathrm{~min}$ at $72{ }^{\circ} \mathrm{C}$ (final extension). The PCR products were separated by electrophoresis in $1.5 \%$ agarose gels in $1 \mathrm{x}$ Tris-borate EDTA (TBE; $89 \mathrm{mM}$ Tris, $89 \mathrm{mM}$ boric acid, $2 \mathrm{mM}$ EDTA) buffer, stained with ethidium bromide $\left(0.5 \mu \mathrm{g} \mathrm{mL}{ }^{-1}\right)$ for 1 min and visualized under UV light in a transilluminator.

After verification of the amplified bands, $40 \mu \mathrm{L}$ aliquots of PCR product from each sample were sent to Macrogen (Seoul, South Korea) to be purified and sequenced in forward and reverse directions with the same primers.

\section{Phylogenetic analyses}

Sequences were manually corrected using the BioEdit software (Hall 2012) The corrected ITS and EF1- $\alpha$ sequences were separately aligned using the CLUSTALW procedure in the BioEdit software (Table 1). After this, the sequences were concatenated in the BioEdit and aligned together with sequences retrieved from the National Center for Biotechnology Information (NCBI), including a sequence of Macrophomina phaseolina used as an outgroup. This alignment was corrected manually, and gaps (-) were used whenever necessary for missing data. Phylogenetic relationships were inferred with the Bayesian method using the Markov chain Monte Carlo procedure for each separated gene, and substitution models of nucleotides were determined by the MrMODELTEST 2.3 (Posada \& Buckley 2004) program according to the Bayesian information criterion (BIC). The multiple alignment (ITS + EF1- $\alpha$ ) was analysed using MrBayes v.3.1.1 program (Ronquist \& Heulsenbeck 2003) with 100 million generations by including each phylogenetic tree of the sample space from each run every 500 generations.

Phylogenetic trees were visualized using FigTree program (Rambaut 2009) and were exported for editing in graphical programs. The obtained sequences (Table 1) were deposited in GenBank at the NCBI site, and the multiple alignments were deposited in the TreeBASE (http://www.treebase.org/) platform under number 19422.

\section{Morphological and physiological characterization}

Pycnidia were produced on colonies grown on sterile Petri plates containing PCA medium supplemented with pine needles, incubated for 4 weeks at $25^{\circ} \mathrm{C}$ and under a $12 \mathrm{~h}$ photoperiod of ultraviolet light.

Fruiting bodies were manually removed and disrupted using scalpels, mounted on slides, stained with a drop of lactophenol and then observed through a light microscope. Thirty measurements were taken from all possible morphological characters displayed (conidia, paraphyses and conidiogenous cells). Images were obtained using a ICc5 131 Axiocam digital camera coupled to a microscope (Carl Zeiss AG Imager.A2, Göttingen, Germany) and a Motic Image Plus 2.0 imaging device (Motic Group Co., Beijing, China).

The growth of all isolates under different temperatures was evaluated by growing them on PDA and storing them under a $12 \mathrm{~h}$ photoperiod. Temperatures of $5,10,15,20,25,30,35$ and $40{ }^{\circ} \mathrm{C}$ were evaluated. Means of mycelial growth were subjected to regression analysis to determine the optimal growth temperature of each species.

The effect of the culture media on growth of some isolates was evaluated using the following media: oats-agar (AvA, $75 \mathrm{~g}$ of oats, $17 \mathrm{~g}$ of agar, $1 \mathrm{~L}$ of water), potato dextrose agar (synthetic PDA, $\left.39 \mathrm{~g} \mathrm{~L}^{-1}\right)$, PCA (20 $\mathrm{g}$ of potato, 20 $\mathrm{g}$ of carrot, $17 \mathrm{~g}$ of agar, $1 \mathrm{~L}$ of water), $\mathrm{V} 8$ juice $\left(100 \mathrm{~mL}\right.$ of V8, $2 \mathrm{~g}$ of $\mathrm{CaCO}_{3}, 17 \mathrm{~g}$ of agar, $900 \mathrm{~mL}$ of water), malt agar extract (MEA, $20 \mathrm{~g}$ of malt extract, $20 \mathrm{~g}$ of dextrose, $1 \mathrm{~g}$ of peptone, $20 \mathrm{~g}$ of agar, $20 \mathrm{~g}$ of dextrose, $1 \mathrm{~L}$ of water) and a medium based on green cashew branches in agar and dextrose ( $200 \mathrm{~g}$ of green cashew branches, $17 \mathrm{~g}$ of dextrose, $17 \mathrm{~g}$ of agar, $1 \mathrm{~L}$ of water), because most isolates came from cashew in the survey. The plates were maintained at $25^{\circ} \mathrm{C}$ and a photoperiod of $12 \mathrm{~h}$. The diameter of the colonies was measured in two perpendicular directions for two consecutive days. The maximum and daily rate of mycelial growth were estimated.

All in vitro trials were conducted in a completely randomized design (DIC), where each plate represented an experimental unit. The mean values were subjected to analysis of variance (ANOVA), followed by the Scott-Knott test at the $5 \%$ level of significance. Data from the test of the effects of different culture media were analysed as a 5-by-3 factorial arrangement in order to determine the interactions. 
TABLE 1. Isolates of Botryosphaeriaceae species used in this study.

\begin{tabular}{|c|c|c|c|c|c|c|}
\hline \multirow[t]{2}{*}{ Specie } & \multirow[t]{2}{*}{ Isolates } & \multirow[t]{2}{*}{ Host } & \multirow[t]{2}{*}{ Origin } & \multirow[t]{2}{*}{ Collection } & \multicolumn{2}{|c|}{ GenBank accession number } \\
\hline & & & & & ITS & TEF1- $\alpha$ \\
\hline Fusicoccum atrovirens & CMW 22682 & $\begin{array}{l}\text { Pterocarpus } \\
\text { angolensis }\end{array}$ & Africa & J. Mehl/J. Roux & FJ888476 & FJ888457 \\
\hline F. atrovirens & CMW 22674 & P. angolensis & Africa & J. Mehl/J. Roux & FJ888473 & FJ888456 \\
\hline F. fabicercianum & CMW 24703 & Eucalyptus grandis & China & $\begin{array}{l}\text { M.J Wingfield/ } \\
\text { X.D.Zhou }\end{array}$ & HQ332195 & HQ332211 \\
\hline F. fabicercianum & CMW 27094 & Eucalyptus sp. & China & M.J Wingfield & HQ332197 & HQ332213 \\
\hline F. ramosum & CBS122069 & E. camaldulensis & Australia & D. Pavlic & EU144055 & EU144070 \\
\hline $\begin{array}{l}\text { Macrophomina } \\
\text { phaseolina }\end{array}$ & PD112 & Prunus dulcis & Australia & $\begin{array}{l}\text { D. Pavlic/MJ. } \\
\text { Wingfield }\end{array}$ & GU251105 & GU251237 \\
\hline $\begin{array}{l}\text { Neofusicoccum } \\
\text { algeriense }\end{array}$ & CBS137504 & Vitis vinifera & Algeria & A. Berraf-Tebbal & KJ657702 & KJ657715 \\
\hline N. algeriense & ALG9 & $V$. vinifera & Algeria & A. Berraf-Tebbal & KJ657704 & KJ657721 \\
\hline N. andinum & CBS 117453 & Eucalyptus sp. & Venezuela & S. Mohali & AY693976 & AY693977 \\
\hline N. andinum & CBS 117452 & Eucalyptus sp. & Venezuela & M.J. Wingfield & DQ306263 & DQ306264 \\
\hline N. arbuti & CBS 116131 & Arbutus menziesii & UEA & M. Elliott & GU251152 & GU251284 \\
\hline N. arbuti & CBS 117090 & A. menziesii & UEA & M. Elliott & GU251154 & GU251286 \\
\hline N. australe & CMW 6837 & Acacia sp. & Australia & M.J Wingfield & AY339262 & AY339270 \\
\hline N. australe & CMW 6853 & Sequoiadendron & Australia & M.J Wingfield & AY339263 & AY339271 \\
\hline N. batangarum & CMW 28363 & Terminalia catappa & Africa & $\begin{array}{l}\text { D. Begoude/J. } \\
\text { Roux }\end{array}$ & FJ900607 & FJ900653 \\
\hline N. batangarum & CMW 283205 & T. catappa & Africa & $\begin{array}{l}\text { D. Begoude/J. } \\
\text { Roux }\end{array}$ & FJ900608 & FJ800654 \\
\hline N. brasiliense & CMM 1269 & Mangifera indica & Brazil & M.W Marques & JX513629 & JX513609 \\
\hline N. brasiliense & IBL447 & Psidium guajava & $\begin{array}{l}\text { Cruz/CE/ } \\
\text { Brazil }\end{array}$ & $\begin{array}{l}\text { I.B.L Coutinho/ } \\
\text { J.S Lima }\end{array}$ & KT247455 & KT247457 \\
\hline N. brasiliense & CMM 1285 & M. indica & Brazil & M.W Marques & JX513628 & JX513608 \\
\hline N. cordaticola & CMW 13992 & Syzigium cordatum & Africa & D. Pavlic & EU821898 & EU821868 \\
\hline N. cordaticola & CMW 14056 & S. cordatum & Africa & D. Pavlic & EU821903 & EU821873 \\
\hline N. eucalyptorum & CBS 115791 & E. grandis & Africa & H. Smith & AF283686 & AY236891 \\
\hline N. eucalyptorum & CMW 10126 & E. grandis & Africa & H. Smith & AF283687 & AY236892 \\
\hline N. eucalypticola & CMW 6217 & E. rossii & Australia & M.J. Wingfield & AY 615143 & AY615135 \\
\hline N. eucalypticola & CMW 6539 & E. rossii & Australia & M.J. Wingfield & AY 615141 & AY615133 \\
\hline N. kwambonambiense & CMW 14023 & S. cordatum & Africa & D. Pavlic & EU821900 & EU821870 \\
\hline N. kwambonambiense & CMW 14140 & S. cordatum & Africa & D. Pavlic & EU821949 & EU821889 \\
\hline N. kwambonambiense $e^{a}$ & IBL220 & $\begin{array}{l}\text { Anarcadium } \\
\text { occidentale }\end{array}$ & $\begin{array}{l}\text { Pio IX/PI/ } \\
\text { Brazil }\end{array}$ & $\begin{array}{l}\text { I.B.L Coutinho/ } \\
\text { J.S Lima }\end{array}$ & KT247454 & KT247456 \\
\hline N. luteum & CMW 9076 & Malus $\times$ domestica & $\begin{array}{l}\text { Nova } \\
\text { Zelândia }\end{array}$ & S.R. Pennycook & AY 236946 & AY236893 \\
\hline N. luteum & CBS 110299 & V. vinifera & Portugal & A.J.L Phillips & AY 259091 & AY573217 \\
\hline N. macroclavatum & WAC 12445 & E. globulus & Australia & T.I Burguess & DQ093197 & DQ093218 \\
\hline N. macroclavatum & WAC 12446 & E. globulus & Australia & T.I Burguess & DQ093198 & DQ093219 \\
\hline N. mangiferum & CMW 7024 & M. indica & Australia & G.I Johnson & AY615185 & DQ093221 \\
\hline N. mediterraneum & PD 311 & Olea europea & Itália & C. Lazzizera & GU251175 & GU251307 \\
\hline N. mediterraneum & PD 312 & Eucalyptus sp. & Grecia & $\begin{array}{l}\text { M.J Wingfield/ } \\
\text { A.J.L Phillips }\end{array}$ & GU251176 & GU251308 \\
\hline
\end{tabular}


TABLE 1. (Continued)

\begin{tabular}{|c|c|c|c|c|c|c|}
\hline \multirow[t]{2}{*}{ Specie } & \multirow[t]{2}{*}{ Isolates } & \multirow[t]{2}{*}{ Host } & \multirow[t]{2}{*}{ Origin } & \multirow[t]{2}{*}{ Collection } & \multicolumn{2}{|c|}{ GenBank accession number } \\
\hline & & & & & ITS & TEF1- $\alpha$ \\
\hline N. occulatum & CBS 128008 & E. grandis & Australia & T.I Burgess & EU7301030 & EU339509 \\
\hline N. occulatum & MUCC 296 & E.s pellita & Australia & T.I Burgess & EU301034 & EU339512 \\
\hline N. parvum & PD 106 & Prunus dulcis & UEA & T.J Michailides & GU251139 & GU251271 \\
\hline N. parvum & CMM 1291 & M. indica & Brazil & M.W Marques & JX513633 & JX513613 \\
\hline N. ribis & CMW7054 & Ribis rubrum & UEA & B. Slippers & AF241177 & AY236879 \\
\hline N. ribis & CMW 7772 & Ribis sp. & UEA & $\begin{array}{l}\text { B. Slippers/G. } \\
\text { Hudler }\end{array}$ & AY236925 & AY236877 \\
\hline N. ursorum & CBS 122811 & E. arboretum & Africa & H.M Maleme & FJ752746 & FJ752709 \\
\hline N. ursorum & CMW 23790 & E. arboretum & Africa & H.M Maleme & FJ752745 & FJ75270 \\
\hline N. umdonicola & CMW 14058 & S. cordatum & Africa & D. Pavlic & EU821934 & EU821874 \\
\hline N. umdonicola & CMW 14060 & S. cordatum & Africa & D. Pavlic & EU821935 & EU821875 \\
\hline N. viticlavatum & STE-U 5044 & $V$. vinifera & Africa & F. Halleen & AY343381 & AY 343342 \\
\hline N. viticlavatum & STE-U 5041 & V. vinifera & Africa & F. Halleen & AY343380 & AY343341 \\
\hline N. vitifusiforme & STE-U 5050 & V. vinifera & Africa & J.M. Van Niekerk & AY343382 & AY343344 \\
\hline N. vitifusiforme & STE-U 5252 & $V$. vinifera & Africa & J.M. Van Niekerk & AY343383 & AY343343 \\
\hline $\begin{array}{l}\text { Neoscytalidium } \\
\text { hyalinum }\end{array}$ & PD 103 & Ficus carica & UEA & T.J. Michailides & GU251106 & GU251238 \\
\hline Ne. hyalinum & WAC 13284 & M. indica & Australia & J. Ray & GU172382 & GU172414 \\
\hline Ne. hyalinum ${ }^{\mathrm{a}}$ & IBL89 & M. indica & $\begin{array}{l}\text { Varjota/ } \\
\text { CE/Brazil }\end{array}$ & $\begin{array}{l}\text { I.B.L Coutinho/ } \\
\text { J.S Lima }\end{array}$ & KT247460 & KT247458 \\
\hline Ne. hyalinum ${ }^{a}$ & IBL272 & A. occidentale & $\begin{array}{l}\text { Pio IX/ } \\
\text { PI/Brazil }\end{array}$ & $\begin{array}{l}\text { I.B.L Coutinho/ } \\
\text { J.S Lima }\end{array}$ & KT247461 & KT247459 \\
\hline Ne. novaehollandiae & WAC 13275 & M. indica & Australia & J. Ray & GU172400 & GU172432 \\
\hline Ne. novaehollandiae & WAC 13303 & M. indica & Australia & J. Ray & GU172398 & GU172430 \\
\hline $\begin{array}{l}\text { Pseudofusicoccum } \\
\text { ardesiacum }\end{array}$ & WAC 13299 & M. indica & Australia & J. Ray & GU172404 & EU144075 \\
\hline P. ardesiacum & CBS 122062 & Adansonia gibbosa & Australia & D. Pavilic & EU144060 & GU172437 \\
\hline P. adansoniae & CBS 122054 & Eucalyptus sp. & Australia & D. Pavilic & EF585532 & EF585570 \\
\hline P. adansoniae & WAC 13299 & M. indica & Australia & J. Ray & GU172404 & GU172436 \\
\hline P. kimberleyense & CBS 122061 & F. opposita & Australia & D. Pavilic & EU144059 & EU144074 \\
\hline P. kimberleyense & WAC 13293 & M. indica & Australia & J. Ray & GU172406 & GU172438 \\
\hline P. stromaticum & CMW 13435 & E. hybrid & Venezuela & S. Mohali & DQ436935 & DQ436936 \\
\hline P. stromaticum & CMM 3953 & M. indica & Brazil & M.W Marques & JX464102 & JX464109 \\
\hline P. stromaticum & CMM 3961 & M. indica & Brazil & M.W Marques & JX464103 & JX464110 \\
\hline P. stromaticum ${ }^{\mathrm{a}}$ & IBL500 & A. occidentale & $\begin{array}{l}\text { Pio IX/ } \\
\text { PI/Brazil }\end{array}$ & $\begin{array}{l}\text { I.B.L Coutinho/ } \\
\text { J.S Lima }\end{array}$ & KT247464 & KT247462 \\
\hline P. stromaticum ${ }^{\mathrm{a}}$ & IBL36 & A. occidentale & $\begin{array}{l}\text { Quixadá/ } \\
\text { CE/Brazil }\end{array}$ & $\begin{array}{l}\text { I.B.L Coutinho/ } \\
\text { J.S Lima }\end{array}$ & KT247465 & KT247463 \\
\hline P. olivaceum & CMW22639 & P. angolensis & Africa & J. Mehl \& J Roux & FJ888463 & FJ888439 \\
\hline P. olivaceum & CMW20881 & P. angolensis & Africa & J. Roux & FJ888459 & FJ888437 \\
\hline P. violaceum & CMW20436 & P. angolensis & Africa & J. Roux & FJ888458 & FJ888440 \\
\hline
\end{tabular}

Sequence numbers in bold were obtained in the present study. aEx-type cultures obtained in this study. Abbreviations: USA: United States of America; PI: Piauí; EC: Ceará; ITS: internal transcribed spacer from the ribosomal DNA region; TEF1- $\alpha$ : part of the gene coding for the translation elongation factor 1- $\alpha$; GenBank: NCBI (National Center for Biotechnology Information) database, available at http://www. ncbi.nlm.nih.gov/ 


\section{Pathogenic characterization}

Mango fruits cv. Tommy Atkins and stems of young plants of cashew and "caja-umbu" were inoculated with the six isolates identified in this study. The methodology used for the inoculation of fruits was described by Marques et al. (2013b) where fruits were gently wounded in the middle region with the tip of three sterile pins to a $3 \mathrm{~mm}$ depth prior to placing a $3 \mathrm{~mm}$ agar plug containing mycelium grown on PDA of the isolate to be tested. Non-colonized agar discs were used as control treatments. For young plants, the methodology used for inoculation was described by Lima et al. (2013), and consisted of making a $2 \mathrm{~mm}$ diameter hole in the stem of the plant at approximately $15 \mathrm{~cm}$ from the bottom with an electric drill. Then, a $2 \mathrm{~mm}$ diameter agar plug containing mycelium grown on PDA was introduced into the hole, placing it in contact with the vascular system of the plant. The hole was covered with petroleum jelly and sealed with Parafilm. In the control treatment, the plants were drilled and inoculated with PDA medium agar plugs only. Both were conducted under the same experimental conditions proposed by Coutinho et al. (2016). In fruits, the diameter of the lesions was measured daily for 7 days using a digital caliper. In plants, the evaluation was made on 15 days after inoculation by measuring the necrotic lesion caused by the infection both longitudinally and perpendicularly. The mean lesion diameters in the fruits on the $4^{\text {th }}$ day and in the stems of the young plants on the $15^{\text {th }}$ day after inoculation were used in the statistical analysis of the data. The experiments were conducted in a completely randomized design consisting of six replicates, where each replicate was composed of one fruit or one young plant of each plant species. Data from the disease progression in mango fruits were evaluated based on nonlinear regression equations to verify the pathogenic ability of each isolate.

\section{Results}

\section{Sampling and fungal isolation}

This study resulted from a large sampling of tropical fruit plants showing typical symptoms induced by fungi in the Botryosphaeriaceae, such as gummosis and die-back. The sampling encompassed the Ceará (73.6\%), Paraíba (1.9\%), Pernambuco (5.7\%), Piauí (15.1\%) and Rio Grande do Norte (3.8\%) states in the Northeast region of Brazil. The plants sampled were cashew (41.5\%), Spondias (26.4\%), mango (7.5\%), coconut (3.8\%), Annonaceae (11.3\%) and other tropical fruit plants (9.4\%). From this sampling, 108 isolates of Botryosphaeriaceae were obtained, with 102 representing Lasiodiplodia species, which were characterized by Coutinho et al. (2016). The other six isolates were identified as Fusicoccum-like and are discussed in the present study.

\section{Molecular characterization}

ITS1 and ITS2, including the 5.8S subunit and partial EF-1 $\alpha$ regions were sequenced for six isolates. The alignment dataset comprised sequences from this study and the sequences from ex-type strains from Botryosphaeriaceae species from GenBank (Table 1). The phylogenetic tree generated (Fig. 1) was inferred by Bayesian analysis (IB) using BIC models: TrNef $+\mathrm{G}$ for the ITS region and $\mathrm{K} 80+\mathrm{G}$ for the TEF- $1 \alpha$ region.

Alignments were composed of 74 taxa and length of the concatenated sequences was 674 nucleotides. Therefore, out of the 674 characters found in the alignment, 402 were preserved, 258 were variables and 234 were parsimony informative. The phylogenetic tree was composed of 74 taxa, including 22 clades containing Neofusicoccum species, six clades containing Pseudofusicoccum species, two clades containing Neoscytalidium species, three clades containing Fusicoccum species and one clade containing Macrophomina phaseolina. The isolates identified in this study were grouped with Neofusicoccum kwambonambiensee (IBL220) obtained from guava plants located in the state of Ceará, $N$. brasiliense (IBL447) obtained from guava plants located in the state of Ceará, ditto hyalinum obtained from cashew trees in the state of Piauí (IBL272) and mango in Ceará state (IBL89), and P. stromaticum obtained from a cashew tree in Ceará (IBL36) and Piauí (IBL500) (Table 1). Well-defined clades were formed with low values of Bayesian inference brackets for the clades $N$. brasiliense and N. kwambonambiense (Fig. 1).

\section{Morphological and physiological characterization}

The conidial morphology of isolates was compared with the morphological description of each species, except for $N$. kwambonambiensee (IBL220) (Table 2). All these isolates produced pycnidia in PCA medium plus Pinus needles after four weeks of incubation. 


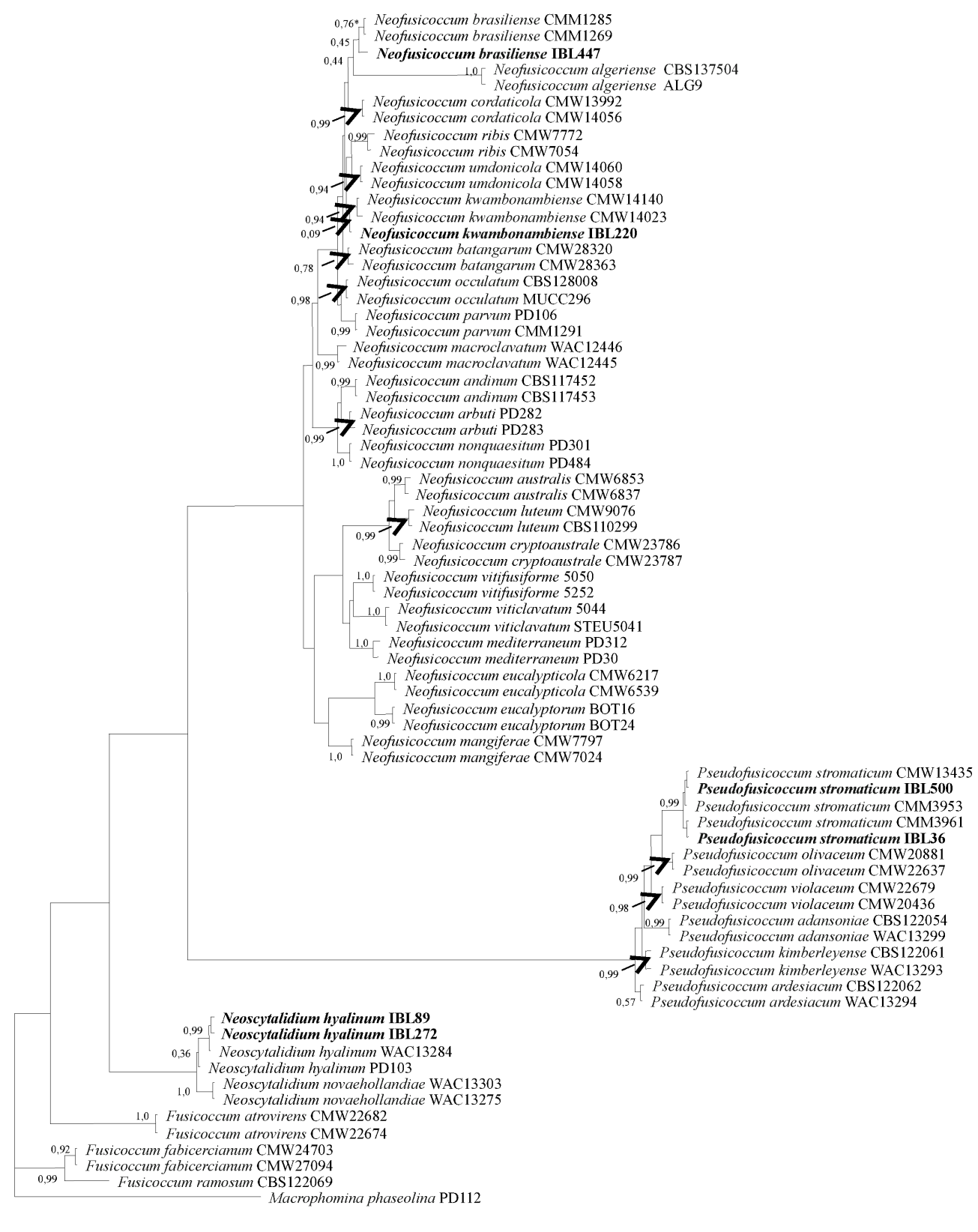

FIGURE 1. Multilocus phylogenetic tree inferred from Bayesian analysis based on the combined sequences of the ITS, TEF-1 $\alpha$. Bayesian posterior probabilities are indicated above the nodes. The tree was rooted to Macrophomina phaseolina PD112. The species in this study are highlighted in bold and grey highlight.

TABLE 2 Comparison of morphological characteristics of Botryosphaeriaceae species examined in this study with those in previous studies.

\begin{tabular}{|c|c|c|c|}
\hline \multirow[t]{2}{*}{ Species } & Conidia length $(\mathrm{L}) \times$ width $(\mathrm{W})$ & L:W & References \\
\hline & \multicolumn{3}{|l|}{ Size $(\mu \mathrm{m})$} \\
\hline \multirow[t]{2}{*}{ Neocytalidium hyalinum } & $19,93(24,83) 27,91 \times 8,88(10,46) 11,93$ & 2,37 & This study \\
\hline & $10-16(-21) \times 3.5-6.5$ & - & Phillips et al. 2013 \\
\hline Neofusicoccum brasiliense & $10,72(21,30) 25,57 \times 8,31(10,18) 11,94$ & 2,09 & This study \\
\hline Neofusicoccum kwambonambiense & $16(22,3) 28 \times 5(6,3) 8$ & 3,6 & Crous et al. 2006 \\
\hline \multirow[t]{2}{*}{ Pseudofusicoccum stromaticum } & $20,05(26,01) 31,46 \times 5,18(6,39) 7,6$ & 4,09 & This study \\
\hline & $(19-) 20-23(-24) \times 5,0(4,0) 6,0$ & 4,0 & Mohali et al. 2006 \\
\hline
\end{tabular}


The $P$. stromaticum isolates had conidial dimensions close to those of the isolate first described by Mohali et al. (2006) and to isolates from the Brazilian territory described by Marques et al. (2013b). N. kwambonambiense (IBL220) never sporulated. The size of the conidia of the $N$. brasiliense isolate (IBL447) was not compared to that of any other isolates of the same species, since its original description was based only on molecular data (Marques et al. 2013).

A quadratic model fitted the growth response to temperature (Table 3). Regression analyses showed that the optimal temperatures for the growth of $N$. brasiliense, $N$. kwambonambiense and one isolate of P. stromaticum (IBL36) were below $26{ }^{\circ} \mathrm{C}$. Up to the third day, no isolate reached the diameter of the plate (90 mm). Ne. hyalinum and $P$. stromaticum began to grow only above $15^{\circ} \mathrm{C}$, and Neofusicoccum spp. began growing at $10{ }^{\circ} \mathrm{C}$. Only the isolates of Ne. hyalinum were able to grow at $40^{\circ} \mathrm{C}$.

TABLE 3 Mycelial growth ( $\mathrm{mm}$ ) of Botryosphaeriaceae species at their respective optimal growth temperatures.

\begin{tabular}{llllll}
\hline Species & Isolates & $\begin{array}{c}\text { Optimum temp. } \\
\left({ }^{\circ} \mathbf{C}\right)\end{array}$ & $\begin{array}{c}\text { Maximum growth at } \\
\text { optimum temp. }(\mathbf{m m})_{\mathbf{b}}\end{array}$ & Equation $_{\mathbf{c}}$ & $\mathbf{R}^{\mathbf{2}}$ \\
\hline N. brasiliense & IBL447 & 24,09 & 86,33 & $\mathrm{y}=-0,29 \mathrm{x}^{2}+14,11 \mathrm{x}-83,71$ & 0,85 \\
N. kwambonambiense & IBL220 & 23,40 & 70,98 & $\mathrm{y}=-0,26 \mathrm{x}^{2}+12,29 \mathrm{x}-72,87$ & 0,73 \\
Ne. hyalinum & IBL89 & 26,43 & 85,03 & $\mathrm{y}=-0,23 \mathrm{x}^{2}+12,47 \mathrm{x}-79,86$ & 0,78 \\
Ne. hyalinum & IBL272 & 26,11 & 82,25 & $\mathrm{y}=-0,24 \mathrm{x}^{2}+12,48 \mathrm{x}-80,77$ & 0,75 \\
P. stromaticum & IBL500 & 26,05 & 51,24 & $\mathrm{y}=-0,16 \mathrm{x}^{2}+8,41 \mathrm{x}-58,35$ & 0,52 \\
P. stromaticum & IBL36 & 24,24 & 51,14 & $\mathrm{y}=-0,1634 \mathrm{x}^{2}+7,92 \mathrm{x}-44,9$ & 0,82 \\
\hline
\end{tabular}

a Temperature in which the pathogen reached maximum growth.

${ }_{\mathrm{b}}$ Maximum mycelial growth on the third day of incubation at optimum temperature.

Regression equation representing the polynomial curve of mycelial growth of each isolates during the temperatures tested: $5,10,15,20$, $25,30,35,40^{\circ} \mathrm{C}$.

d Correlation coefficient

All isolates showed mycelial mass that was whitish on the third day of incubation, and became darker with further incubation. Mycelial growth in the different culture medium according to ANOVA showed interactions among these factors (Fig. 2A).

Potato dextrose agar, V8, MEA and AvA medium favoured Neoscytalidium hyalinum and N. brasiliense growth without differing from one another, and the same effect was detected for P. stromaticum in the V8 medium. The CajuDA and BCA media favoured the mycelial growth of the three studied species, but only Neofusicoccum sp. reached $100 \%$ of the diameter of petri dishes.

Neoscytalidium hyalinum reached $100 \%$ growth on the BDA, V8, MEA and AvA media but reached only $66.66 \%$ and $38 \%$ growth on CajuDA and BCA, respectively. The growth rate of this species did not differ among the different types of culture media, except for the BCA medium, which provided growth of $10 \mathrm{~mm} \mathrm{day}^{-1}$, whereas it provided 35-50 mm day ${ }^{-1}$ for the other species (Fig. 2A,B). The mycelial growth of Neofusicoccum sp. was not favoured by the BCA medium (Fig. 2A).

\section{Emended description}

\section{Neofusicoccum brasiliense}

Phylogenetic description:-M.W. Marques, A.J.L. Phillips \& M.P.S. Câmara MycoBank MB80473 (Marques et al. 2013).

Morphological description:-I.B.L. Coutinho, C.S. Lima \& J.E. Cardoso. MycoLibrary:-CMM 4576.

Sexual morph: not observed. Asexual morph.: Production of pycnidia after 8 days in pine needles embedded in PCA and sporulation after 17 days under the same conditions. Conidia hyaline, fusiform, base subtruncate to bluntly rounded, non-septate, smooth with granular contents. Dimensions: 10.7$25.6 \times 8.3-11.9 \mu \mathrm{m}($ mean $=21.3 \times 10.2 \mu \mathrm{m} ; \mathrm{L}: \mathrm{W}=2.1, \mathrm{n}=50)$. Mycelium abundant, cotonous and dark in BDA, malt extract, oats and V8. Production of red pigment in BDA at $35^{\circ} \mathrm{C}$. Habitat: Necrotic cankers in branches and trunks of Psidium guajava. 
Fig. 2A

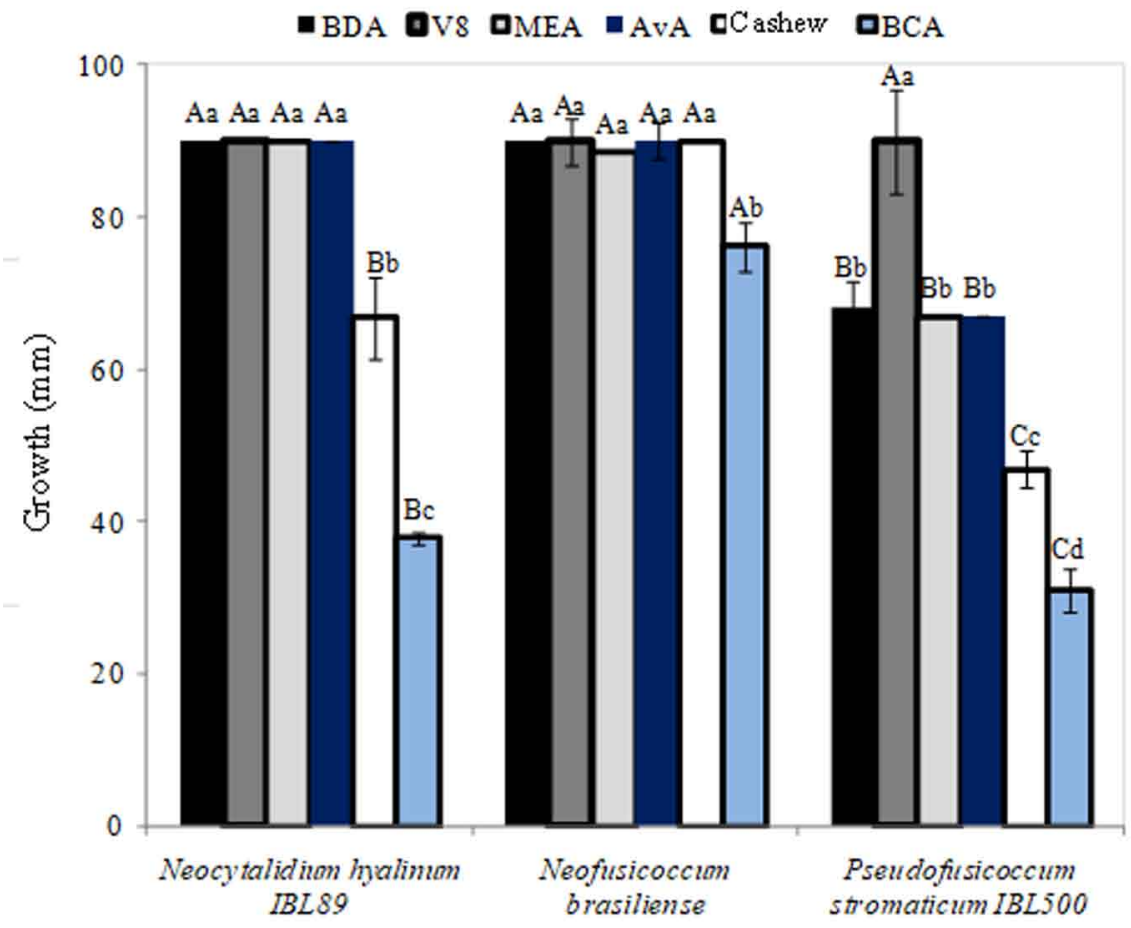

Fig. 2B

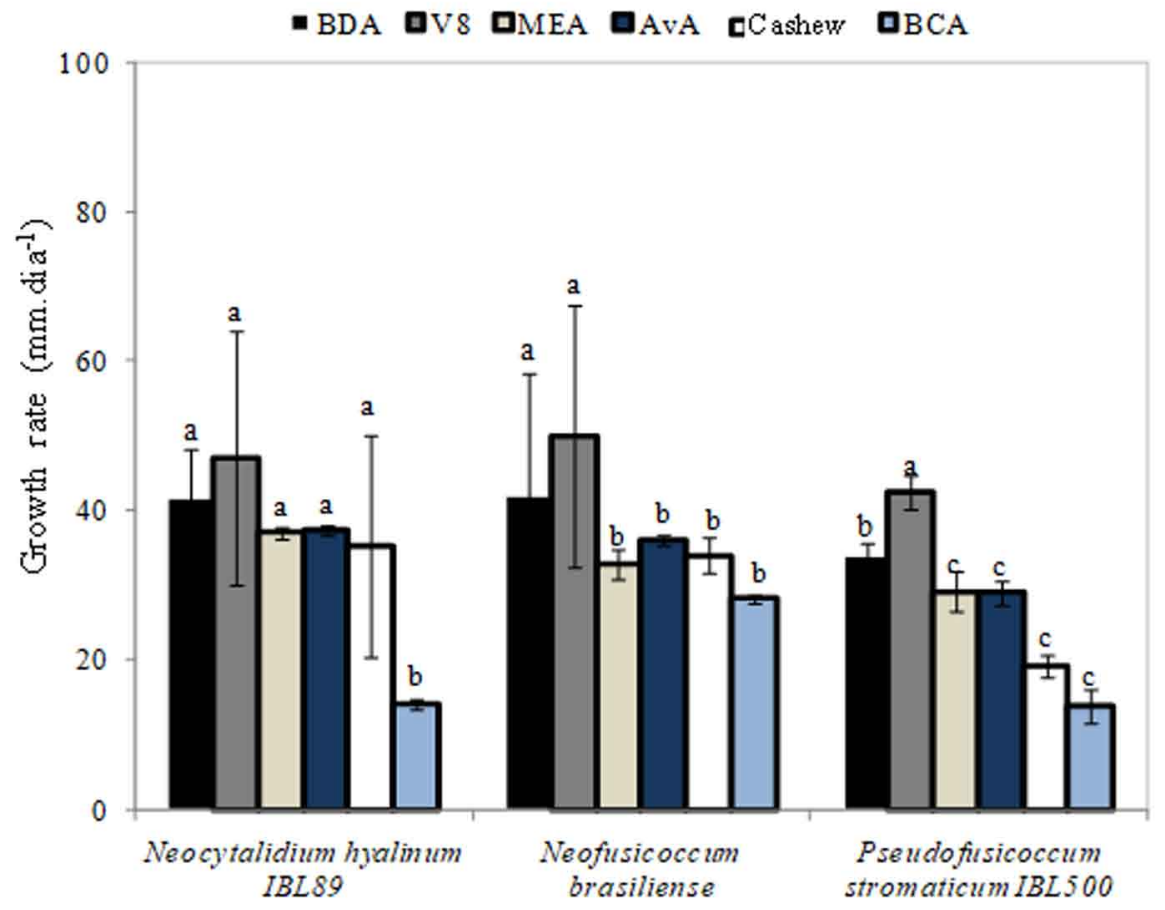

FIGURE 2. Mycelial growth (A) and in vitro growth rate (B) of Botryosphaeriaceae species on the third day of incubation in different culture media. Fig, 2A: There was a positive interaction between the factors of culture media and species. Thus, the same uppercase letters for each culture medium within the species factor indicate no difference among media, and the same lowercase letters within the species factor for each culture medium indicate no difference among species. The means were compared by the Scott-Knott test at $\mathrm{P}=0.05$. Fig. 2B: There was no positive interaction between the factors of culture media and species. Thus, averages followed by the same lowercase letters within each species do not differ by Scott-Knott's test at $\mathrm{P}=0.05$. 
Geographic distribution:-Ceará State, Brazil.

Specimens examined:-BRAZIL. Ceará State: Cruz city (latitude: -2.91941 , longitude: $-40.17032^{\circ} 55^{\prime} 10^{\prime \prime} \mathrm{S}$, $40^{\circ} 10^{\prime} 13^{\prime \prime}$ E), October 2013, collected by I.B.L Coutinho \& J.S. Lima, culture ex-holotype CMM 4576, NCBI GenBank access codes KT247455 (ITS) and KT247457 (EF1- $\alpha$ ).

Pathogenicity characterization

All species were virulent when the mango fruits and young plants of cashew and "caja-umbu" were inoculated, but to different degrees of severity depending on the host (Fig. 3). N. kwambonambiense, $N$. brasiliense and $P$. stromaticum (IBL36) were highly aggressive when inoculated into mango fruit, cashew and "caja-umbu" seedlings, causing the greatest lesion length (Fig. 3). In cashew, Ne. hyalinum (IBL272) and P. stromaticum (IBL500) were the least aggressive, while in mango fruit, Ne. hyalinum (IBL272) was moderately aggressive, followed by Ne. hyalinum (IBL89) and P. stromaticum (IBL500), which were the least aggressive.

In "caja-umbu" seedlings, Ne. hyalinum (IBL272) and Ne. hyalinum (IBL89) were moderately virulent without significant differences, followed by P. stromaticum (IBL500), which was the least virulent isolate among all inoculated hosts (Fig. 3).

The symptoms in mango fruits were seen 3 days after inoculation by any isolate, but $N$. brasiliense was the most virulent species, reaching a maximum growth rate of $18.4 \mathrm{~mm} \mathrm{day}^{-1}$. Symptoms in mango fruit were necrotic and watery lesions that grew towards the peduncle and were mummified at the end. The most virulent species stimulated gum exudation by both cashew and "caja-umbu" seedlings, causing superficial cankers in their stem tissues that later progressed to large, necrotic lesions.

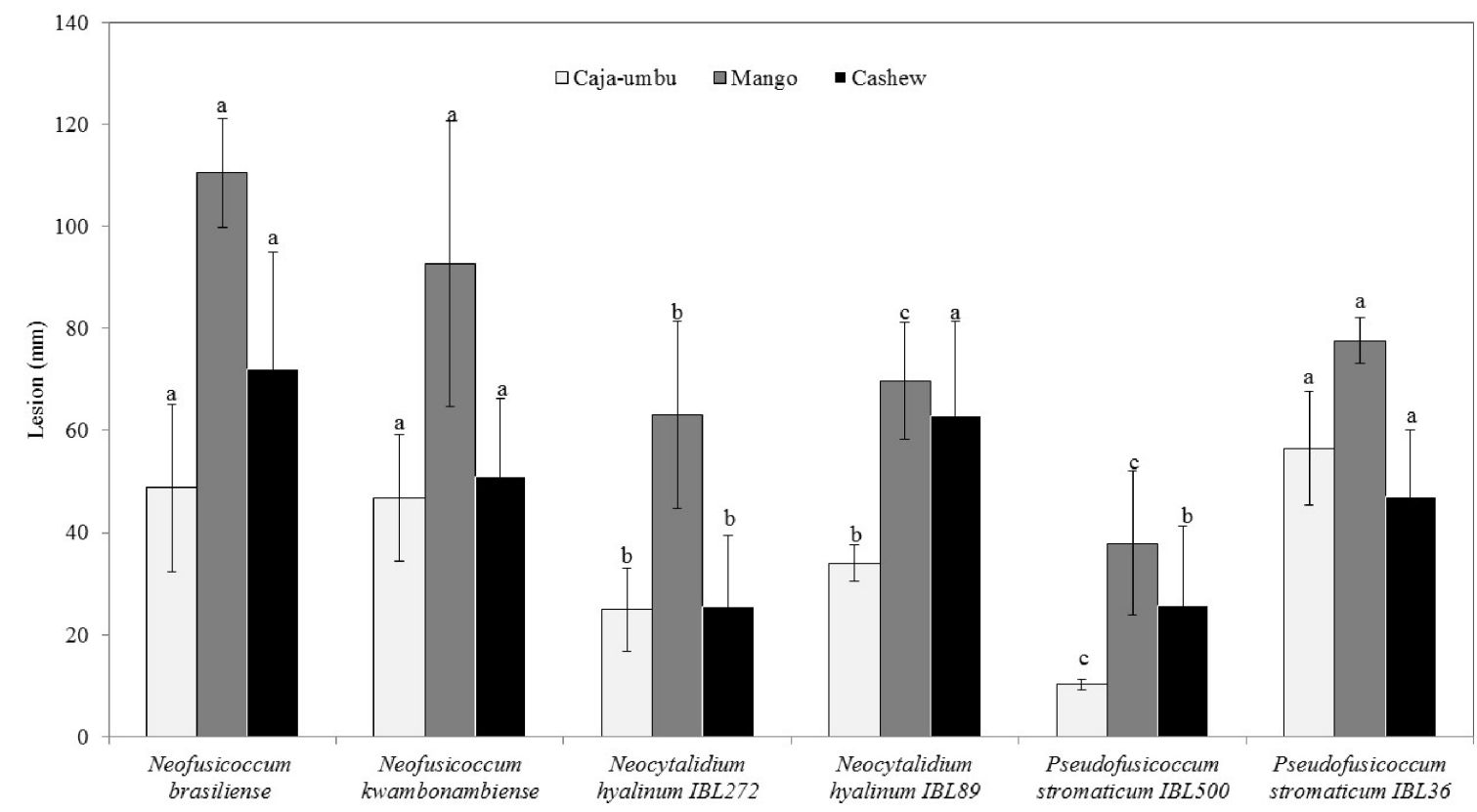

FIGURE 3. Mean lesion length $(\mathrm{mm})$ caused by Botryosphaeriaceae species associated with dieback and stem-end rot in several tropical fruit trees from Northeast Brazil: 45 days after inoculation in stems of young plants of caja-umbu, 15 days after inoculation in stems of young cashew plants and four days after inoculation in injured mango fruits. Bars above columns represent the standard error of the mean. For each host, columns with the same letter do not differ significantly according to Scott-Knott's test at a = 0.05.

\section{Discussion}

Four species of Botryosphaeriaceae (Neoscytalidium hyalinum, Neofusicoccum kwambonambiense, Neofusicoccum brasiliense and Pseudofusicoccum stromaticum) were associated with dieback and canker in the stems and trunks of cashew, mango and guava in Northeast Brazil.

The genera Neoscytalidium and Pseudofusicoccum were easily identified by their conidial morphology, as they presented characteristics that were comparable to previously described species (Phillips et al. 2013). N. kwambonambiense failed to sporulate, and morphological features of its conidia could therefore not be assessed. 
Until now, the description of $N$. brasiliense was based on molecular data only (Marques et al. 2013). The present study provides the first morphological description of $N$. brasiliense. The identification of Botryosphaeriaceae at the species level by means of DNA-based phylogeny (ITS, TEF1- $\alpha$ ) and morphological characteristics clearly provide unquestionable support for the taxonomy of this family.

Previously, phylogenetic inferences based on ITS sequences were the most current and valid tools for fungal identification and the establishment of phylogenetic descriptions of the genera Neofusicoccum, Neoscytalidium and Pseudofusicoccum, formerly considered Botryosphaeria and Fusicoccum anamorphs (Crous et al. 2006). Nowadays, Botryosphaeriaceae species are frequently recognized and separated by DNA sequence differences, through multiple phylogenetic inferences, which emphasize protein coding genes such as EF1- $\alpha$ (Abdollahzadeh et al. 2010, Phillips et al. 2013, Berraf-Tebbal et al. 2014). However, for some genera such as Neofusicoccum, to distinguish between species, additional genes are required to provide a more robust phylogenetic basis (Abdollahzadeh et al. 2010, Phillips et al. 2013).

In this study, different clades of Neofusicoccum sp. that presented low values of Bayesian inference were formed, evidencing the close relationships among them. As for the Neoscytalidium and Pseudofusicoccum clades, however, the ITS and EF1- $\alpha$ regions showed enough consistency to distinguish species. Based on this information, the phylogenetic analysis of Botryosphaeriaceae should be further explored and standardized in order to guarantee more reproducibility of phylogenetic results. Obviously, the goals of the study would determine the specific genes to be used, considering that for the Botryosphaeriaceae, a combination of ITS and EF1- $\alpha$ genes is commonly used.

This study is the first report of Ne. hyalinum, Ne. kwambonambiense, N. brasiliense and P. stromaticum associated with cashew plants and $N$. brasiliense associated with guava. The occurrence, distribution and epidemiology of these fungi in fruit plants assume great importance for the development of the tropical fruit industry, especially for cashew and guava.

Botryosphaeriaceae has been reported to be associated with mango trees, and this has revealed the importance of this group of pathogens in relation to yield declines and damage to fruits post harvest (Costa et al. 2010, Sakalidis et al. 2011, Marques et al. 2013, Abdollahzadeh et al. 2013). Due to these numerous and frequent occurrences in mango, it is suggested that the centre of origin of these fungi is in the northern hemisphere, even in temperate regions, with further dissemination to tropical regions by the accidental transport of infected plants (Marques et al. 2013).

Neofusicoccum parvum and $N$. ribis have been reported to cause post-harvest rot in guava fruits in Brazil (Nogueira Junior et al. 2015). The species studied here all had a similar growth response to temperature, with optimum temperature around $25^{\circ} \mathrm{C}$ with limiting ranges of $\leq 10{ }^{\circ} \mathrm{C}$ and $\geq 40{ }^{\circ} \mathrm{C}$. These results are in agreement with studies on the germination of N. parvum and B. dothidea conidia (Nogueira Junior et al. 2015) and the growth of N. parvum, N. brasiliense, Ne. hyalinum and P. stromaticum (Marques et al. 2013).

Neofusicoccum is commonly associated with numerous woody hosts worldwide (von Arx 1987) and currently has 22 phylogenetically described species (Berraf-Tebbal et al. 2014). N. brasiliense has been described in Northeast Brazil associated with fruit rot in mango (Marques et al. 2013); thus, this is the second report of this species in Brazil and the first in guava branches.

N. kwambonambiense was described for the first time in South Africa in asymptomatic stems, leaves and fruits of dead plants of Syzygium cordatum (Pavilic et al. 2009, Phillips et al. 2013) and was later reported in grapevines in Uruguay (Abreo et al. 2013), and to cause fruit rot in post-harvested strawberry in Brazil (Lopes et al. 2014). The occurrence of $N$. kwambonambiense associated with symptoms of dieback and canker in stems of cashew plants is unprecedented in Brazilian territory. Such findings become relevant from a pathological point of view, as even at low frequencies and distributions, ecological changes may be occurring to allow the flow of this fungal species from its centre of origin to Brazilian hosts. Both $N$. brasiliense and $N$. kwambonambiense isolates were able to cause necrotic lesions when inoculated on mango fruits and the stems of cashew and "caja-umbu" seedlings.

The Botryosphaeriaceae have been described in association with mango and other woody species, including cashew and "caja-umbu"; however, it is not clear whether these fungi have been fully described in terms of their role as pathogens, especially in woody tropical hosts. This is very important for economic reasons for the development of control measures that ensure good management practices, such as sanitation.

The isolation of Botryosphaeriaceae from asymptomatic tissues evidences the dissemination and infection of tissues through mechanical pruning and the use of infected pruning machinery. The Botryosphaeriaceae are successful as opportunistic endophytic colonizers, which has thus enabled them to occur for long periods of time as latent pathogens causing post-harvest rot (Slippers \& Wingfield 2007, Sakalidis et al. 2011).

In cashew orchards, in addition to mechanical pruning, propagation via grafting is a routine practice in commercial crop production. Reported studies have shown the dissemination of Botryosphaeriaceae, such as Lasiodiplodia spp., in 
cashew by infected plant scions used for grafting (Cardoso et al. 2009) in addition to through the use of non-disinfested pruning instruments (Cardoso et al. 1998). Based on this evidence, a lack of sanitation practices favours the occurrence and the dissemination of Botryosphaeriaceae in orchards of tropical fruit trees.

Diseases caused by Neoscytalidium spp., Ne. hyalinum ( $=$ Ne. dimidiatum) and Ne. novaehollandiae tend to be common in tropical countries (Phillips et al. 2013). Ne. hyalinum has been reported in association with freeze-stressed Citrus plants in California and with necrotic lesions (Phillips et al. 2013). In Italy, it has been detected in branches of Citrus spp. causing canker and gummosis (Polizzi et al. 2009, 2011). In Brazil, this species has been reported in Jatropha curcas, cassava (Manihot esculenta) and mango tree (Machado et al. 2012, 2014a, b, Marques et al. 2013b).

P. stromaticum was originally described in asymptomatic plants as well as in branches and stems of dead plants of Acacia mangium, Eucalyptus and Pinus in Venezuela (Mohali et al. 2006, 2007). It is associated with native host plants in Australia, especially in unexplored forests (Pavilic et al. 2008). Later, this species was reported in association with declining mango trees in intensively cultivated orchards in Brazil as the second most abundant species in a recent survey, overturning the myth that its distribution was restricted to native hosts of unexplored lands (Marques et al. 2012, 2013).

Botryosphaeriaceae is well known to lack host specificity (Slippers \& Wingfield 2007), which suggests that the expansion of the distribution, colonization, and speciation of this family has been influenced by environmental factors (Sakadilis et al. 2013), such as climate and associated microflora (Pitt et al. 2010, Sakadilis et al. 2011). Therefore, additional studies are needed to determine the relationship between environmental conditions in different biomes and the presence of such numerous species of Botryosphaeriaceae in diverse hosts in Brazil and around the world. In view of this, it is evident that studies such as this one will stimulate continuing research dealing with the epidemiology of these new reports of Botryosphaeriaceae recently described in the literature.

\section{References}

Abdollahzadeh, J. \& Jvadi, A., Mohammadi-Goltapeh, E., Zare, R. \& Phillips, A.J.L. (2010) Phylogeny and morphology of four new species of Lasiodiplodia from Iran. Persoonia 25: 1-10.

https://doi.org/10.3767/003158510X524150

Abreo, E., Martinez, S., Bettucci, L. \& Lupo, S. (2013) Characterization of Botryosphaeriaceae species associated with grapevines in Uruguay. Australasian Plant Pathology 42 (3): 241-249.

https://doi.org/10.1007/s13313-013-0200-8

Arx, J.A von. (1987) Plant Pathogenic Fungi. J. Cramer, Berlin, Germany.

Barroso, G.M. (1991) Sistemática de Angiospermas do Brasil. In: Imprensa Universitária, vol. 2.

Berraf-Tebbal, A., Guereiro, M.A. \& Phillips, A.J.L. (2014) Phylogeny of Neofusicoccum species associated with grapevine trunk diseases in Algeria, with description of Neofusicoccum algeriense sp. nov. Phytopathologia Mediterranea 53 (3): 416-427.

Cardoso, J.E., Freire, F.C.O., Sá, F.T. \& Souza, R.N.M. (1998) Dissemination and control of resinose in severed cashew tree trunks for replacement cup. n. 17. Press Release, Empresa Brasileira de Pesquisa Agropecuária, Centro Nacional de Pesquisa de Agroindústria Tropical, pp. 1-4.

Cardoso, J.E., Vidal, J.C., Santos, A.A., Freire, F.C.O. \& Viana, F.M.P. (2002) First report of black branch dieback of cashew caused by Lasiodiplodia theobromae in Brazil. Plant Disease 86 (5): 558. https://doi.org/10.1094/PDIS.2002.86.5.558B

Cardoso, J.E., Bezerra, M.A., Viana, F.M.P., Sousa, T.R.M., Cysne, A.Q. \& Farias, F.C. (2009) Endophytic occurrence of Lasiodiplodia theobromae in cashew tissues and its transmission by propagules. Summa Phytopathologica 35 (4): 262-266. https://doi.org/10.1590/S0100-54052009000400002

Costa, V.S.O., Michereff, S.J., Martins, R.B., Gava, C.AT., Mizubuti, E.S.G. \& Câmara, M.P.S. (2010) Species of Botryosphaeriaceae associated on mango in Brazil. European Journal Plant Pathology 127: 509-519. https://doi.org/10.1007/s10658-010-9616-y

Coutinho, I.B.L., Freire, F.C.O., Lima, C.S., Lima, J.S., Gonçalves, F.J.T., Machado, A.R.A., Silva, M.S. \& Cardoso, J.E. (2017) Diversity of genus Lasiodiplodia associated with perennial tropical fruit plants in northeastern Brazil. Plant Pathology 66: 90-104. https://doi.org/10.1111/ppa.12565

Crous, P.W., Slippers, B., Wingfield, M.J., Rheeder, J., Marasas, W.F.O., Phillips, A.J.L., Alves, A., Burgess, T., Barber, P. \& Groenewald, J.Z. (2006) Phylogenetic lineages in the Botryosphaeriaceae. Studies in Mycology 55: 235-253. 
https://doi.org/10.3114/sim.55.1.235

Denman, S., Crous, P.W., Taylor, J.E., Kang, J.C., Pascoe, I. \& Wingfield, M.J. (2000) An overview of the taxonomic history of Botryosphaeria, and a re-evaluation of its anamorphs based on morphology and ITS rDNA phylogeny. Studies in Mycology 45: 129-140.

Freire, F.C.O. (1991) A resinose do cajueiro. EMBRAPA-CNPCa [Caju Informativo] 4 (1): 1-2.

Freire, F.C.O., Cardoso, J.E., Viana, F.M.P. \& Martins, M.V.V. (2011) Status of Lasiodiplodia theobromae as a plant pathogen in Brazil. Essentia 12: 53-71.

Gonçalves, F.J.T., Freire, F.C.O., Lima, J.S., Melo, J.G.M. \& Câmara, M.P.S. (2016) Pathogenicity of endophytic Botryosphaeriaceae species from the caatinga plants of Ceará state in mango and umbu-cajá. Summa Phytopathol 42 (1): $43-52$.

https://doi.org/10.1590/0100-5405/2099

Hawksworth, D.L. (2011) A new dawn for the naming of fungi: impacts of decisions made in Melbourne in July 2011 on the future publication and regulation of fungal names. MycoKeys 1: 7-20.

https://doi.org/10.3897/mycokeys.1.2062

Hibbett, D.S. \& Taylor, J.W. (2013) Fungal systematics: is a new age of enlightenment at hand? Nature Reviews Microbiology 11 (2): 129-133. https://doi.org/10.1038/nrmicro2963

Ismail, A.M., Cirvilleri, G., Polizzi, G., Crous, P.W., Groenewald, J.Z. \& Lombard, L. (2012) Lasiodiplodia species associated with dieback disease of mango (Mangifera indica) in Egypt. Australasian Plant Pathology 41: 649-660. https://doi.org/10.1007/s13313-012-0163-1

Jacobs, K.A. \& Rehner, S.A. (1998) Comparison of cultural and morphological characters and ITS sequences in anamorphs of Botryosphaeria and related taxa. Mycologia 90: 601-610. https://doi.org/10.2307/3761219

Lima, J.S., Moreira, R.C., Cardoso, J.E., Martins, M.V.V. \& Viana, F.M.P. (2013) Cultural, morphological and pathogenic characterization of Lasiodiplodia theobromae associated with tropical fruit plants. Summa Phytopathologica 39: 81-88. https://doi.org/10.1590/S0100-54052013000200001

Lopes, U.P., Zambolim, L., Pinho, D.B., Barros, A.V., Costa, H. \& Pereira, O.L. (2014) Postharvest rot and mummification of strawberry fruits caused by Neofusicoccum parvum and N. kwambonambiense in Brazil. Tropical Plant Pathology 39 (2): 178-183. https://doi.org/10.1590/S1982-56762014000200009

Machado, A.R., Pinho, D.B., Dutra, D.C., Pereira, O.L. (2012) First report of collar and root rot of physic nut (Jatropha curcas) caused by Neoscytalidium dimidiatum in Brazil. Plant Disease 96 (11): 1697. https://doi.org/10.1094/PDIS-05-12-0504-PDN

Machado, A.R., Pinho, D.B. \& Pereira, O.L. (2014a). Phylogeny, identification and pathogenicity of the Botryosphaeriaceae associated with collar and root rot of the biofuel plant Jatropha curcas in Brazil, with a description of new species of Lasiodiplodia. Fungal Diversity 67: 231-247. https://doi.org/10.1007/s13225-013-0274-1

Machado, A.R., Pinho, D.B, Oliveira, S.A.S. \& Pereira, O.L. (2014b). New occurrences of Botryosphaeriaceae causing black root rot of cassava in Brazil. Tropical Plant Pathology 39 (6): 464-470. https://doi.org/10.1590/S1982-56762014000600008

Marques, M.W., Lima, N.B., Morais, JR, M.A., Barbosa, M.A.G., Souza, B.O, Michereff, S.J, Phillips, A.J.L. \& Camara, M.P.S. (2013a) Species of Lasiodiplodia associated with mango in Brazil. Fungal Diversity 61: 181-193. https://doi.org/10.1007/s13225-013-0231-z

Marques, M.W, Lima, N.B, Morais, JR, M.A., Michereff, S.J., Phillips, A.J.L. \& Câmara, M.P.S. (2013b). Botryosphaeria, Neofusicoccum, Neoscytalidium and Pseudofusicoccum species associated with mango in Brazil. Fungal Diversity 61: 195-208. https://doi.org/10.1007/s13225-013-0258-1

Pavlic, D., Slippers, B., Coutinho, T.A., Gryzenhout, M. \& Wingfield, M.J. (2004) Lasiodiplodia gonubiensis sp. nov. a new Botryosphaeria anamorph from native Syzygium cordatum in South Africa. Studies in Mycology 50: 313-322.

Phillips, A.J.L., Alves, A., Abdollahzadeh, J., Slippers, B., Wingfield, M.J., Groenewald, J.Z. \& Crous, P.W. (2013) The Botryosphaeriaceae: genera and species known from culture. Studies in Mycology 76: 51-167. https://doi.org/10.3114/sim0021

Pickel, D.B.J. (2008) Flora do Nordeste do Brasil segundo Piso e Marcgrave: no século XVII/ Argus Vasconcelos de Almeida (Editor). - Recife, EDUFRPE. 312 p.

Pitt, W.M., Huang, R., Steel, C.C. \& Savocchia, S. (2010) Identification, distribution and current taxonomy of Botryosphaeriaceae species associated with grapevine decline in New South Wales and South Australia. Australian Journal of Grape and Wine Research 16: 258-271. 
https://doi.org/10.1111/j.1755-0238.2009.00087.x

Polizzi, G., Aiello, D., Vitale, A., Giuffrida, F., Groenewald, J.Z. \& Crous, P.W. (2009) First report of shoot blight, canker, and gummosis caused by Neoscytalidium dimidiatum on citrus in Italy. Plant Disease 93: 12-15.

https://doi.org/10.1094/PDIS-93-11-1215A

Polizzi, G., Aiello, D., Castello, I., Vitale, A., Groenewald, J.Z. \& Crous, P.W. (2011) Occurrence, molecular characterisation, and pathogenicity of Neoscytalidium dimidiatum on citrus in Italy. Acta Horticulturae 892: 237-243.

https://doi.org/10.17660/ActaHortic.2011.892.27

Sakalidis, M.L., Ray, J.D., Lanoiselet, V., Hardy, G.E.J. \& Burgess, T.I. (2011) Pathogenic Botryosphaeriaceae associated with Mangifera indica in the Kimberley Region of Western Australia. European Journal Plant Pathology 130: 379-391.

https://doi.org/10.1007/s10658-011-9760-z

Sakalidis, M.L, Slippers, B., Wingfield, B.D., Hardy, G.E.ST.J. \& Burgess, T.I. (2013) The challenge of understanding the origin, pathways and extent of fungal invasions: global populations of the Neofusicoccum parvum-N. ribis species complex. Diversity and Distributions 19: 873-883.

https://doi.org/10.1111/ddi.12030

Slippers, B. \& Wingfield, M.J. (2007) Botryosphaeriaceae as endophytes and latent pathogens of woody plants: diversity, ecology and impact. Fungal Biology Reviews 21: 90-106.

https://doi.org/10.1016/j.fbr.2007.06.002

Slippers, P.W., Crous, S.D., Coutinho, T.A., Wingfield, B.D. \& Wingfield, M.J. (2004) Combined multiple gene genealogies and phenotypic characters differentiate several species previously identified as Botryosphaeria dothidea. Mycologia 96 (1): 83-101. https://doi.org/10.1080/15572536.2005.11833000

Tavares, S.C.C.H. (2002) Epidemiology and integrated management of Botryodiplodia theobromae - current situation in Brazil and in the world. Fitopatologia Brasileira 27: 46-52. 